Saskatoon Catholic Schools Foundation, and is mandated to expose students to real-life field study of prairie ecology.

\section{Acknowledgements}

Last Mountain Bird Observatory manager $\mathrm{Al}$ Smith has generously shared his time and expertise. Bird Studies Canada is also to be thanked for assistance with some of the initial start-up costs. Station volunteers include members from the Saskatoon Nature Society, the University of Saskatchewan Extension Division, the Saskatoon Zoo Society, University of Saskatchewan students, as well as staff and students from Saskatoon schools. Special thanks to CWS biologist Brenda Dale for providing additional training opportunities for the volunteers.

1. SMITH, A.R. 1996. Atlas of Saskatchewan Birds. Saskatchewan Natural History Society Special Publication No. 22. Nature Saskatchewan, Regina.

\title{
FIRST BREEDING RECORD OF THE DOUBLE-CRESTED CORMORANT IN THE CRESTON VALLEY, BRITISH COLUMBIA
}

\section{LINDA M. VAN DAMME, $61920^{\text {th }}$ Avenue; S, Creston, BC V0B 1G5.}

\section{E-mail:1vd2@shaw.ca}

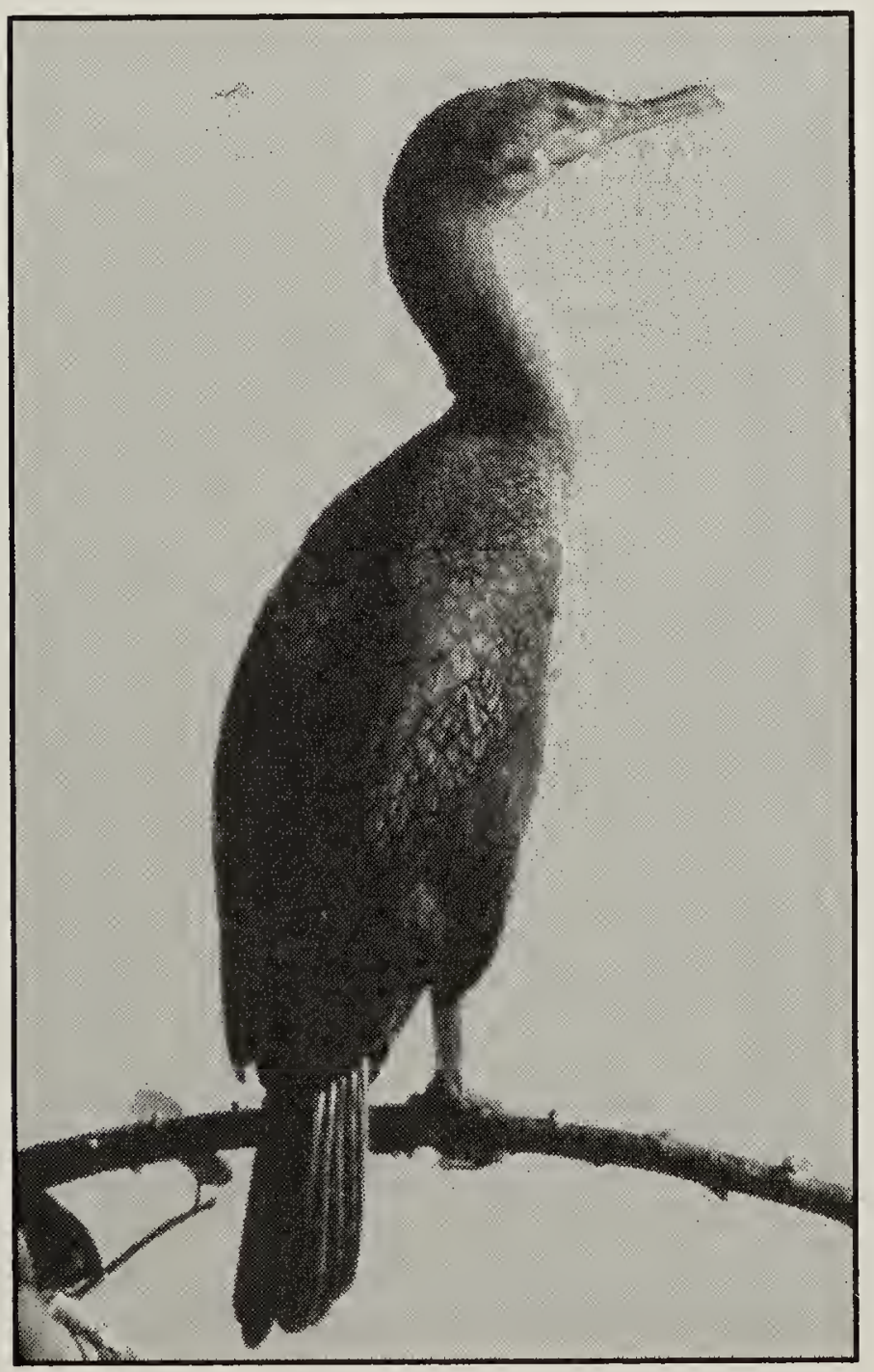

\section{Double-crested Cormorant}

R. Wayne Campbell

\section{Introduction}

The Double-crested Cormorant breeds throughout much of central interior North America, where major concentrations are centered on lakes in the prairie provinces. ${ }^{6,7}$ Smaller numbers breed locally on the Pacific coast and along the Atlantic coast.

In British Columbia, the Double-crested Cormorant breeds regularly in the Strait of Georgia, where it is present year-round. ${ }^{2}$ In the interior, breeding was first confirmed in 1993 when four pairs were found nesting in an American White Pelican colony at Stum Lake, west of Williams Lake. ${ }^{9}$ The only other interior breeding record dates from 1997 when a pair was observed feeding two young on the Cheslatta River, southeast of Burns Lake in the center of the province (Guy Monty, pers. comm.).

This paper documents the third interior breeding of Double-crested Cormorants in British Columbia and discusses interspecific competition with a long-established Great Blue Heron colony known as the Leach Lake colony. 


\section{Study Area and Historical Changes}

Creston Valley, $110 \mathrm{~km}$ west of Cranbrook, in extreme south-central British Columbia, is well known for its diversity and abundance of birds.' Double-crested Cormorants were first recorded in the valley in 1982 when a single bird was sighted flying along the Kootenay River (S. Forbes, pers.comm.). During the following decade, 1 to 12 cormorants were regularly reported from late June to late September with the exception of 1988 when 20 cormorants were observed. ${ }^{13}$ From 1993 to 1999 , up to eight birds were frequently observed from early May to late September, and since 2000, cormorant numbers have ranged between 12 and 28 birds annually (pers. obs.). Breeding was suspected but not confirmed for the years 1999 to 2002 when adult and juvenile cormorants were observed perched on deadheads in the Kootenay River.

\section{Field Observations in 2003}

On 31 May, while monitoring Osprey nests along the Kootenay River, I observed four adult Double-crested Cormorants within the Creston Valley Wildlife Management Area (CVWMA) on the eastern boundary of the Leach Lake Unit. The cormorants were perched high in mature, riparian Black Cottonwood (Populus balsamifera ssp. trichocarpa) trees occupied by a breeding colony of Great Blue Herons. The cormorants appeared to be on territory and were vocalizing loudly with hoarse, guttural calls.

On 6 June, an adult cormorant was observed sitting in a small stick nest, (nest $\# 1$ ), approximately $28 \mathrm{~m}$ from the ground in a live cottonwood tree also occupied by two pairs of nesting Great Blue Herons. The cormorant's mate delivered live cottonwood branches to the nest, which were then woven into the existing base. The pair was observed copulating at the nest. A second adult cormorant was observed sitting in a nest, (nest \#2) of green-leafed cottonwood branches built in the crotch of a large dead branch on a live cottonwood tree unoccupied by herons.
On 9 June, nest \#1 was complete and an adult cormorant was noted in an incubating position. In nest \#2, an adult was weaving nesting materials while sitting in the nest as its mate perched nearby. On this visit, a third pair of cormorants was building a nest (nest \#3) in the same cottonwood tree as nest \#1. One member of this third pair perched on a branch and tucked live green cottonwood boughs under its body, bending them to weave around a nearby vertical branch.

On 16 June, nest \#3 was complete with many new, green cottonwood branches added. Three adults were observed sitting low in nests, with only heads and tails visible. Visits made on 27 June and 8 July confirmed that the nests were still active as three adults remained in incubating positions.

Young were first observed in nests \#1 and \#2 on 15 July. In nest \#1, a naked, wobblynecked nestling was observed moving about at the adult's side while being brooded. A single chick observed in nest \#2 was more mobile and poked its head up near the adult's wing. Although the adult in nest \#3 frequently shifted its position, no young were observed. In the second week of July, southern British Columbia was in the throes of a heat wave with daily temperatures in the Creston Valley ranging between $33-37^{\circ} \mathrm{C}$.

During late July, nestling activity was observed in each nest. An adult was sitting high in nest \#1 where two black downy young with short bills and pale yellow throat skin were observed moving about in the nest. The mate arrived and fed both young. At nest \#2 the adult was sitting on the nest rim and two black downy young were observed. When the mate arrived to feed the young, two smaller nestlings suddenly appeared thrusting their heads up with gaping mouths and were fed a regurgitated liquid. At nest \#3 a naked wobbly-necked young shifted its position at the adult's side.

During an early morning visit on 27 July, 2 immature cormorants and 19 adults, in 
addition to the 3 brooding adults, were perched in the upper canopy of the cottonwood trees. The nestlings were larger and more active in the nests. There continued to be two young in nest \#1 (although a week later only one chick was observed), four young in nest \#2, and three in nest \#3. All were different sizes.

On 11 August, a total of eight young were observed standing in three nests, cloaked in black "woollies" but larger in size, with wing feathers developing and a deepening yellow hue on the throat pouch. The temperature on 11 August was $38^{\circ} \mathrm{C}$ and at nest $\# 2$ an adult cormorant was twice observed "watering" all four chicks. The adult flew a short distance upriver and, upon returning, inserted its head into a chick's mouth, allowing water to pour in for 2-10 seconds. Kuiken observed this behaviour at Doré Lake, Saskatchewan and suggests that "watering" occurs to compensate for the evaporation of water from the inner surface of the gular pouch on warm, sunny days. ${ }^{8}$

By 19 August, all eight young had welldeveloped wing, tail and body feathers. The parents were perched on nearby branches as their broods occupied the entire nest. Feeding was observed at two of the nests when an adult maneuvered to the rim while the hungry young vied for a spot close to the adult, poking and pulling at its gular sac until one young inserted its head into the adult's throat where food was regurgitated.

During the fourth week in August, the young now unattended by adults, were more mobile, leaving the nest to perch on nearby denuded tree branches and were observed stretching and flapping their wings in preparation for flight. It was surprising how "whitewashed" their webbed feet had become during the nestling period.

On 30 August, one young from nest $\# 2$ took flight down river and returned to the nest. Three of the eight young had fledged by 3 September, although all returned to the nest trees to be fed by the adults. By 7 September, all the young had fledged. This nest site was occupied for 98 days. The three pairs of Double-crested Cormorants successfully fledged eight young for an average of 2.7 young/nest.

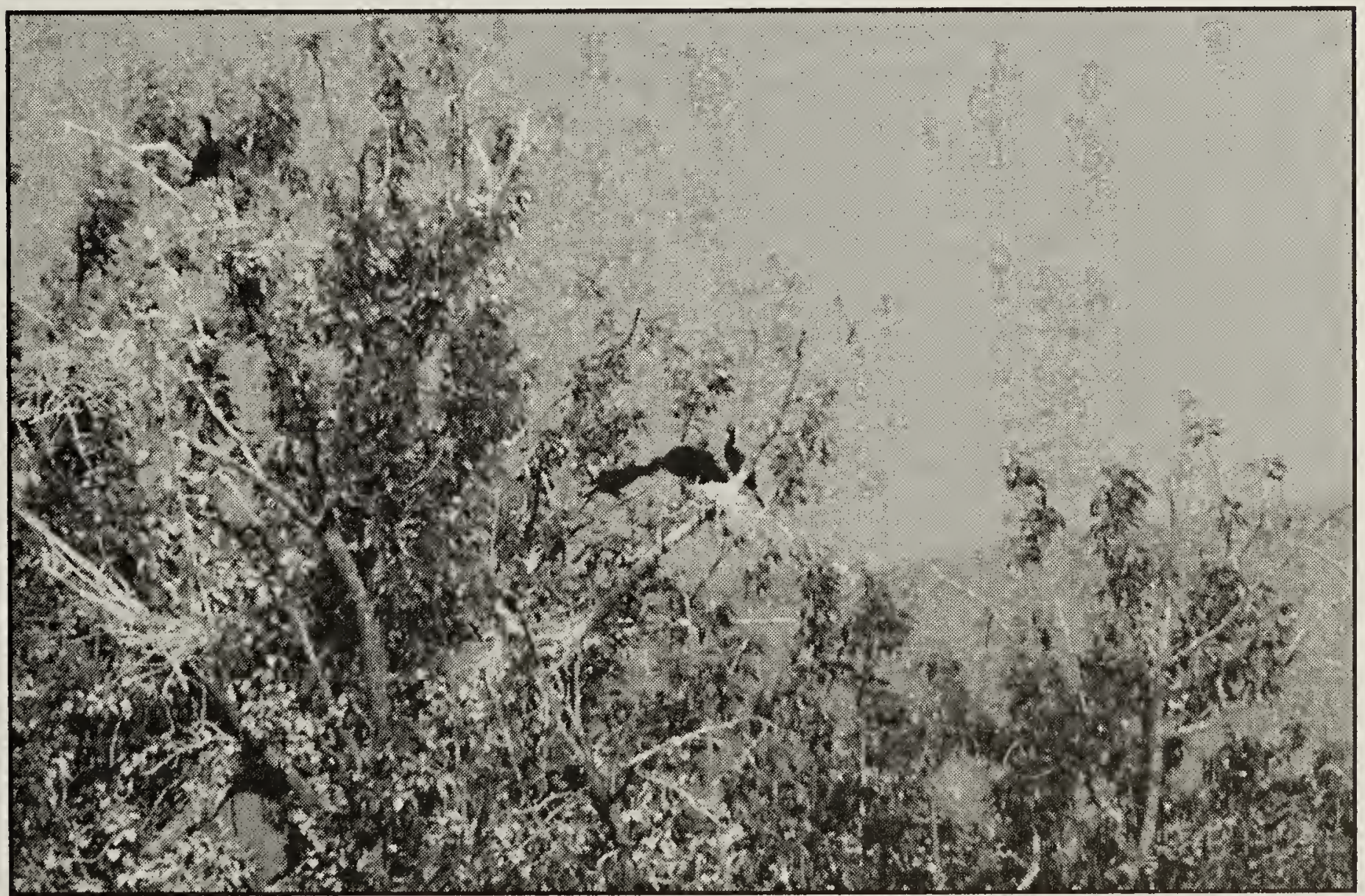




\section{Discussion}

The first successful nesting of Doublecrested Cormorants in the Creston Valley is likely due to the ideal nest sites in mature, riparian Black Cottonwood trees-sites safe from ground predators and close to feeding areas at Leach Lake and on the Kootenay River within $4 \mathrm{~km}$ of the colony. Wires et al. suggest that feeding sites should be within $10 \mathrm{~km}$ for successful colonies. ${ }^{14}$

The Double-crested Cormorant feeds on a wide variety of fishes, diving in shallow water to catch prey, which range from 3-40 $\mathrm{cm}$ in length. Preferred prey measures less than $15 \mathrm{~cm} .{ }^{14}$ Warm-water fishes available in the CVWMA marshes and sloughs include pumpkinseed (Lepomis gibbosus), yellow perch (Perca flavescens), largemouth bass (Micropterus salmoides), and black bullhead (Ictalurus melas). Northern squawfish (Ptychocheilus oregonensis), redside shiner (Richardsonius balteatus), largescale sucker (Catostomus macrocheilus), peamouth chub (Mylocheilus caurinus), and longnose sucker (C. catostomus) also occur in the Kootenay River and nearby Duck Lake., ${ }^{40}$

\section{Potential Impacts of Nesting Cormorants}

Nesting Double-crested Cormorants may have several effects on other colonial waterbird species including competition for nest sites and prey, and habitat degradation. In the 2003 breeding season, Great Blue Herons returned to the Leach Lake nest trees in early to mid-March, and by mid-April many adults appeared to be incubating. No competition for nest sites from Doublecrested Cormorants was observed.

The most immediate impacts occur through nest substrate defoliation and tree die-off from droppings. ${ }^{14}$ Leaves and small branches are stripped from nearby trees and the weight of birds and their nests can break branches. ${ }^{12}$ The mature stands of Black Cottonwood trees along the Kootenay River were heavily "white-washed" by both herons and cormorants during the 2003 nesting season and the branches which supported the cormorant nests were completely denuded. Most colonial waterbirds damage vegetation at breeding and/or roosting sites and cormorants cause some of the most dramatic changes. ${ }^{14}$ Cormorants can destroy their nest trees due to the seasonal accumulation of guano. The highly acidic droppings affect foliage and also disturb the ionic equilibrium in forest soils. Some colonies that have become established in coniferous or deciduous stands killed the trees within 3 to 10 years due to guano deposition. ${ }^{14}$

\section{Disturbances}

In coastal British Columbia, Doublecrested Cormorants nesting on coastal islands have been negatively impacted by Bald Eagles and boat traffic, which cause adults to leave their nests, exposing eggs and chicks to predation by gulls, Common Ravens and Northwestern Crows. ${ }^{3}$ In Creston Valley, although Common Ravens examined unoccupied heron nests, no predatory activity was detected near any active cormorant nests. In mid-July 2003, an Osprey dove repeatedly at an incubating adult cormorant in nest \#3, but the adult did not flush from the nest. While an immature Bald Eagle stood in a stick nest eating a heron in mid-July, the incubating cormorants remained alert, facing in the direction of the eagle (pers. obs.).

During August, forest fires precipitated a flurry of helicopter activity. At times, the pilots flew directly over the nest trees, causing adults and immatures to flush from their perches while the unfledged young cowered in the nest and peered into the sky (pers obs.). Fixed-wing aircraft overflights appeared to have only a modest impact. Since this colony represents the third known breeding site for interior British Columbia, policies regarding minimum flight limits of aircraft, especially helicopter overflight, should be established.

In Canada, the Double-crested Cormorant is considered a species "Not at Risk" by the Committee on the Status of Endangered Wildlife as breeding numbers have been increasing significantly since 1975 throughout most of its range. ${ }^{6}$ It is protected by 
provincial wildlife acts in the prairie provinces and in British Columbia. Pacific coast populations have declined, prompting the British Columbia Ministry of Water, Land and Air Protection to elevate the listing to "Red".

\section{The future}

Since Double-crested Cormorants have extreme fidelity to established colony sites, it is likely that birds will return to the Leach Lake heron colony. ${ }^{14}$ Although both the Great Blue Heron and Double-crested Cormorant require similar nest sites (e.g. tops of mature trees), there appears to be little or no competition between the two species at the present time. During 25 years of surveys in the United States Great Lakes regions, the United States Department of Interior Fish and Wildlife Service has found that nesting cormorants have had minimal impact on heron activity and vice versa."

As part of a long-term monitoring program established in the mid-1970s for interior colonial nesting birds in British Columbia, it will be important over the next decade to research subsequent breeding activity of Double-crested Cormorants, their effects on nesting Great Blue Herons, and impacts to the vegetative structure of the Leach Lake nesting colony.

\section{Acknowledgements}

I wish to thank Robert Louie of the Lower Kootenay Indian Band for access to private land. I would also like to thank Cyril Colonel for observation notes and photodocumentation throughout the nesting period. R. Wayne Campbell kindly provided helpful editorial comments and supplied the close-up photograph of an adult cormorant.

1. BUTLER, R.W., B.G. STUSHNOFF, and E.MCMACKIN. 1986. The birds of the Creston Valley and southeastern British Columbia. Canadian Wildlife Service Occasional Paper. No. 58, Ottawa, Ontario. 37 pp.

2. CAMPBELL, R.W., N.K. DAWE, I. MCTAGGARTCOWAN, J.M. COOPER, G.W. KAISER, and M.C.E. MCNALL. 1990. The Birds of British Columbia. Volume 1 Nonpasserines. Introduction, Loons through
Waterfowl. Royal British Columbia Museum and Canadian Wildlife Service, Victoria. 514 pp.

3. CHATWIN, T.A., M. MATHER, and T.GIESBRECHT. 2001. Double-crested and Pelagic Cormorant Inventory in the Strait of Georgia in 2000. Central West Coast Forest Association. 20 pp

4. FORBES, L. S. 1985. The feeding ecology of Western Grebes breeding at Duck Lake, British Columbia. M.Sc. thesis, University of Manitoba, Winnipeg. 72 pp.

5. FORBES, L. S. 1989 Environmental variability and geotypic conflicts during reproduction in families of ospreys. Ph.D. thesis, Simon Fraser University, Burnaby, B.C. 164pp

6. HATCH, J.J. 1995. Changing populations of Double-crested Cormorants. Colonial Waterbirds 18 (Special Publication 1): 8-24.

7. HATCH, J.J. and D.V. WESELOH. 1999. Doublecrested Cormorant (Phalacrocorax auritus). In The Birds of North America, No. 441 (A. Poole and F. Gill, eds.). The Birds of North America, Inc., Philadelphia, PA. 36 pp.

8. KUIKEN, T. 2001. Watering of Double-crested Cormorant Chicks. Blue Jay 59 (2):73-77.

9. MOUL, I.E. and M.B. GEBAUER. 2001. Status of the Double-crested Cormorant in British Columbia. B.C. Ministry of Water, Land and Air Protection. Wildlife Working report No. WR-105. Victoria. B.C. $36 \mathrm{pp}$.

10. OHANJANIAN, I.A. 1986. The effects of man-made dyke on the reproductive behavior of red-necked Grebes (Podiceps grisigena). M.Sc. thesis. SFU, Burnaby, B.C.

11. United States Department of Interior Fish and Wildlife Service. 2003. Final Environmental Impact Statement: Double-crested Cormorant Management in the United States. 113 pp.

12. WESELOH, D.V.and B. COLLIER. 1995. The Rise of Double-crested Cormorant on the Great Lakes: Winning the War Against Contaminants. Great Lakes Fact Sheet No. En 40-222/2-1995E. Burlington, Ontario: Environment Canada, Canadian Wildlife Service. $11 \mathrm{pp}$.

13. WILSON, S.F. and B. STUSHNOFF. 1992. Wildlife surveys conducted on the Creston Valley Wildlife Management Area, 1969-1991. Technical Report Series No. 161. Canadian Wildlife Service, Pacific and Yukon Region, British Columbia. 71 pp.

14. WIRES, L.R., F.J.CUTHBERT, D.R. TREXEL and A.R. JOSHI. 2001. Status of the Double-crested Cormorant ((Phalacrocorax auritus) in North America. Final report to USFWS. 377 pp. 